\title{
Thyrotropin-Producing Pituitary Adenoma Discovered as a Pituitary Incidentaloma
}

\author{
Noriyoshi Yamakita, Tsuneko IKedA*, Toshihiro MuraI, Takashi Komaki, \\ Toshifumi Hirata** and Kiyoshi Miura
}

\begin{abstract}
A 46-year-old woman with incidentally discovered thyrotropin (TSH)-producing pituitary adenoma showed endocrine data which was consistent with TSH-producing pituitary tumor. However, she showed only slight hyperthyroidism and the oversecretion and autonomous secretion of TSH from the tumor seemed to be limited from the results of several endocrine examinations. Immunohistochemical examination revealed that not only TSH- $\beta$ and TSH- $\alpha$ but also prolactin and growth hormone synthesizing cells were present in the tumor tissue. Pituitary-transcription activator 1 (Pit-1) immunoreactivity was also detected in the adenoma cell nuclei. It was conceivable that the presented TSH-producing adenoma clinically located close to the nonfunctioning adenoma and Pit-1 may have played an important role in the multidirectional differentiation or development of this tumor.
\end{abstract}

(Internal Medicine 34: 1055-1060, 1995)

Key words: Pit-1, immunohistochemistry

\section{Introduction}

Thyrotropin (TSH)-producing pituitary adenoma is relatively rare and constitutes about $1 \%$ of pituitary adenoma (1). The patients usually show symptoms of hyperthyroidism (sweating, palpitation, weight loss, and diffuse goitor), and are often misdiagnosed and treated as Graves' disease (2-4). The tumor is usually huge when discovered. However, since the method of measuring TSH has recently become very sensitive, pituitary tumor can be suspected when the serum TSH level is inappropriately high for the serum thyroid hormone levels even if it is not absolutely high (4). On the other hand, magnetic resonance imaging (MRI) examination has become popular and now the possibility of incidentally discovering pituitary tumor has increased. In adult autopsies the incidence of pituitary microadenoma has varied between 6 and 23\% (1). In one series, the incidence of pituitary tumor with state-of-the-art MRI and gadolinium enhancement has been reported to be $10 \%$ (5). Thus, it is likely that pituitary incidentaloma is not rare. In the present paper we report a patient with incidentally discovered TSH-producing pituitary adenoma who showed only slight symptoms of hyperthyroidism and present results of the immunohistochemistry for several pituitary hormones and pituitarytranscription activator 1 (Pit-1) (6) in the resected tumor.

\section{Materials and Methods}

\section{Hormone measurement}

All hormone levels in serum or plasma were measured by commercially available radioimmunoassay kits except for the measurement of serum TSH- $\alpha$ subunit (TSH- $\alpha$ ) level. Serum free triiodothyronine (fT3) and free thyroxine (fT4) levels were measured by AMERLEX-M free T3 $\mathrm{kit}^{\mathrm{TM}}$ and AMERLEX-M free $\mathrm{T} 4 \mathrm{kit}^{\mathrm{TM}}$ (Amersham International plc, Bucks, UK). Serum TSH level was measured by TSH•RIA BEADS II ${ }^{\mathrm{TM}}$ (Dainabot, Tokyo, Japan). Plasma growth hormone $(\mathrm{GH})$, luteinizing hormone ( $\mathrm{LH})$ and follicle-stimulating hormone (FSH) levels were measured with GH kit Daiichi ${ }^{\mathrm{TM}}$, SPAK-S LH kit ${ }^{\mathrm{TM}}$ and SPAK-S FSH kit ${ }^{\mathrm{TM}}$ (Daiichi Radioisotope, Tokyo, Japan), respectively. Plasma prolactin (PRL) and adrenocorticotropin (ACTH) levels were measured using SPAK$S_{\text {PRL }}{ }^{\mathrm{TM}}$ (Daiichi Radioisotope) and ALLEGRO HS-ACTH ${ }^{\mathrm{TM}}$ (Nichols Institute, Sari Juan Capistrano, CA, USA), respectively, which are immunoradiometric assay systems. Reference ranges of serum or plasma hormone levels were as follows; fT3, $4.65-9.00 \mathrm{pmol} / l ;$ fT4, $10.9-27.7 \mathrm{pmol} / l$; TSH, $0.6-5.1 \mathrm{mU} / l$; TSH- $\alpha, 29.3-353.1 \mathrm{pmol} / l ;$ PRL, $1.4-14.6 \mu \mathrm{g} / l ; \mathrm{GH}, 0.66-3.68$ $\mu \mathrm{g} / l, \mathrm{LH}$ in post menopausal phase, $8.7-38.0 \mathrm{IU} / l ; \mathrm{FSH}$ in post menopausal phase, 26.2-113.3 IU/l; ACTH, 1.98-11.5 pmol/l.

From the Department of Internal Medicine, Clinical Research Center of Endocrinology and Metabolism, *the Department of Pathology and **the Department of Neurosurgery, Matsunami General Hospital, Gifu

Received for publication January 19, 1995; Accepted for publication July 19, 1995

Reprint requests should be addressed to Dr. Noriyoshi Yamakita, the Department of Internal Medicine, Matsunami General Hospital, 185-1 Dendai Kasamatsu, Gifu 501-61 
The molar ratio of serum levels of TSH- $\alpha$ to TSH was calculated on the basis of the following molecular weight values: TSH, 28,000; and TSH- $\alpha, 14,700$ ( $1 \mathrm{ng}$ TSH corresponding to $3.226 \mu \mathrm{U})$.

TSH receptor antibodies (TRAb) in serum were measured by radioreceptor assay using TSH Receptor Antibody $\mathrm{Kit}^{\mathrm{TM}}$ (Incstar Co., Stillwater, MN, USA). Measuring of anti-T3 and anti-T4 antibodies in serum was previously described (7). Serum sex hormone binding globulin (SHBG) level was measured by DELFIA SHBG kit $^{\mathrm{TM}}$ (Wallac, Turku, Finland), with a reference range of $18.6-117 \mathrm{nmol} / \mathrm{l}$.

All studies were performed in accordance with the Helsinki Declaration.

\section{Histological examination}

The pituitary tumor specimen was examined light-microscopically and immunohistochemically. Hematoxyline-eosin and Azan stain were used for the light microscopic examination. The indirect immunoperoxidase method was applied for immunohistochemistry, using antisera specific to TSH (Histofine Anti-TSH Antibody ${ }^{\mathrm{TM}}$, Nichirei, Tokyo, Japan), TSH- $\alpha$ (provided by Dr. T. Yamaji), TSH- $\beta$ subunit (TSH- $\beta$ ) (provided by National Institute of Diabetes and Digestive and Kidney Disease, Bethesda, MD, USA), PRL (Histofine Anti-PRL Antibody ${ }^{\mathrm{TM}}$, Nichirei), GH (mouse anti-human growth hormone $^{\mathrm{TM}}$, Zymed Laboratories Inc., San Francisco, CA, USA), LH (Histofine Anti-LH Antibody ${ }^{\mathrm{TM}}$, Nichirei), and FSH (Histofine Anti-FSH Antibody ${ }^{\mathrm{TM}}$, Nichirei). The cross-reactivity of antisera to TSH with $\mathrm{LH}$ and FSH was $0.1 \%$ and $0.2 \%$, respectively. The production of the anti-human Pit- 1 antibody and the details of the antibody were described elsewhere (8). Two-micron thick sections of paraffin embedded sections were stained for anti-TSH, anti-PRL and anti-GH antibodies. Fourmicron thick ones were stained for anti-TSH- $\alpha$, anti-TSH- $\beta$, anti-LH, anti-FSH, anti-ACTH and anti-Pit-1 antibodies.

\section{Case Report}

\section{Clinical and endocrine findings}

A 46-year-old woman consulted Matsunami General Hospital complaining vertigo on February 20, 1994. She underwent hysterectomy and left ovariectomy six months earlier due to myoma uteri and the left ovarian cyst in a hospital. She showed no remarkable neurological findings on physical examination except for slight nystagmus on the right side in both eyes. The vertigo and nystagmus spontaneously disappeared without any medications in a week. On MRI of the head, however, a pituitary tumor with suprasellar extension and invasion to the left cavernous sinus was revealed (Fig. 1). No visual disturbance was seen on ophthalmological examination. On admission, the skin was moist and Achilles' tendon reflex was slightly accelerated, but no goitor, finger tremor or weight loss was found. Pulse rate was 84/min and blood pressure was 132/84 $\mathrm{mmHg}$. On laboratory examination, blood count and biochemical data were unremarkable. The plasma glucose levels after oral administration of $75 \mathrm{~g}$ glucose showed oxyhyperglycemic pattern, increasing from $5.16 \mathrm{mmol} / l$ to a peak of $11.21 \mathrm{mmol} /$ $l$ at 30 minutes and returning to $6.72 \mathrm{mmol} / l$ at 120 minutes. Serum fT3 and fT4 levels were slightly high or in the upper limit of the reference range, being $10.1-10.7 \mathrm{pmol} / \mathrm{l}$ and $27.4-27.7$ $\mathrm{pmol} / l$, respectively. Serum TSH level was, however, within the normal range (2.3-3.7 mU/l), which was an inappropriately high level for serum fT3 and fT4 levels. Serum SHBG level was slightly high, at $120 \mathrm{nmol} / l$. No diurnal rhythm was shown in serum TSH levels, being $2.2 \mathrm{mU} / \mathrm{l}$ at 0600, 2.0 at 0900, 2.0 at 2100 , and 2.1 at 2300 . Serum TSH- $\alpha$ level was high, at 642 to $925 \mathrm{pmol} / l$. The molar ratio of TSH- $\alpha$ to TSH in serum was high, being 24.5. Basal metabolic rate was normal, being $8 \%$ (reference range, $-10-10 \%$ ) and ${ }^{123} \mathrm{I}$ uptake of thyroid gland for 24 hours was $20 \%$. TRAb and TSBAb were negative, being $4.2 \%$ and $7.5 \%$, respectively. Both of anti-T3 and anti-T4
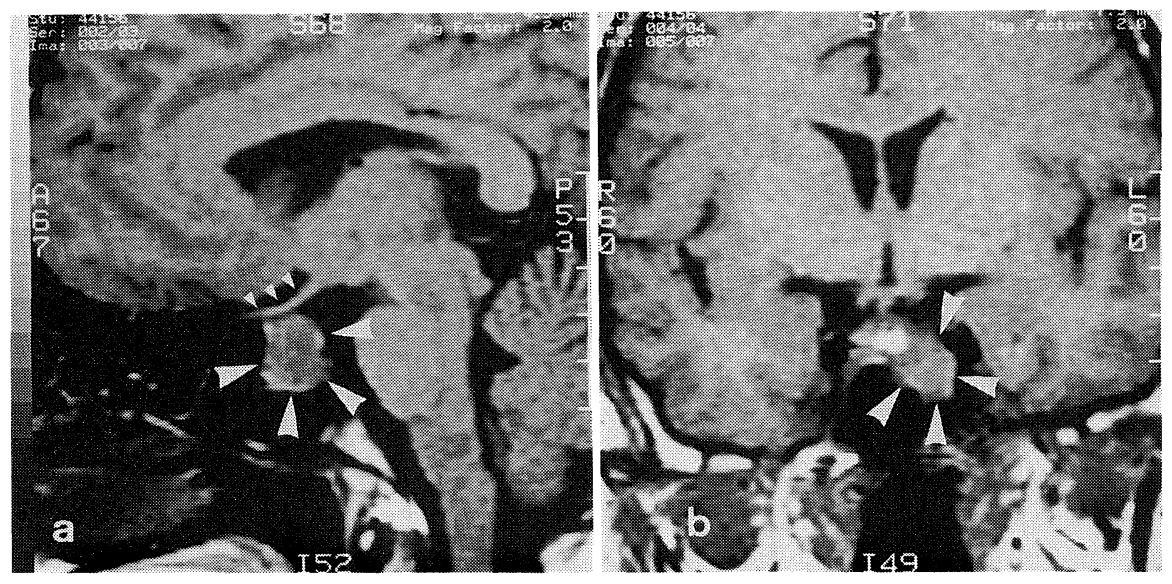

Figure 1. Magnetic resonance imaging of the pituitary tumor. a) Pituitary tumor (large arrowheads) showing suprasellar extension was found in the saggital image. However, the optic nerve (small arrowheads) was still intact. b) In the coronal image, invasion of the pituitary tumor to the left cavernous sinus (large arrowheads) was found. 
antibodies were negative. Antithyroglobulin antibodies and antimicrosomal antibodies were also negative. Serum TSH level did not respond to intravenous administration of $500 \mu \mathrm{g}$ thyrotropin-releasing hormone (TRH test); basal level was 2.2 $\mathrm{mU} / \mathrm{l}$ and peak one was 2.3. No paradoxical response of serum TSH level was shown after intravenous administration of 100 $\mu \mathrm{g}$ gonadotropin-releasing hormone (GnRH test), $100 \mu \mathrm{g} \mathrm{GH}-$ releasing hormone (GRH test) and $100 \mu \mathrm{g}$ corticotropin-releasing hormone (CRH test), respectively. By the oral consecutive administration of $75 \mu \mathrm{g}$ of triiodothyronine daily for 15 days (T3 suppression test), the serum TSH and TSH- $\alpha$ levels were incompletely suppressed $(0.75 \mathrm{mU} / l$ and $520 \mathrm{pmol} / l$ in the final day, respectively) (Fig. 2). However, the molar ratio of serum level of TSH- $\alpha$ to TSH gradually increased during T3 suppression test. At the final day of the administration of T3, ${ }^{123}$ I uptake of thyroid gland for 24 hours was suppressed to $6 \%$. By a single oral administration of $2.5 \mathrm{mg}$ bromocriptine, serum TSH and TSH- $\alpha$ levels slightly decreased from $2.9 \mathrm{mU} / l$ to 1.8 at 12 hours and from $782 \mathrm{pmol} / l$ to 566 at 12 hours, respectively. After a subcutaneous administration of $100 \mu \mathrm{g}$ octreotide acetate, serum TSH and TSH- $\alpha$ levels slightly decreased from $2.1 \mathrm{mU} / \mathrm{l}$ and $642 \mathrm{pmol} / \mathrm{l}$ to 1.7 at 3 hours and 524 at 12 hours, respectively.

Basal plasma levels of other pituitary hormones and their responses to hypothalamic hormones were within normal limits; PRL was $5.6 \mu \mathrm{g} / l$ and increased to 13 by TRH test; $\mathrm{LH}$ and FSH were $23 \mathrm{IU} / l$ and $89 \mathrm{IU} / l$ and increased to 83 and 200 in GnRH test, respectively; $\mathrm{GH}$ was $0.75 \mu \mathrm{g} / \mathrm{l}$ and increased to 45 in GRH test; ACTH was $3.74 \mathrm{pmol} / l$ and increased to 15.2 in CRH test. The increase of the plasma PRL level in GnRH, GRH and $\mathrm{CRH}$ tests was equivocal. However, the plasma $\mathrm{GH}$ level paradoxically increased from 0.19 and $0.20 \mu \mathrm{g} / \mathrm{l}$ to 3.0 and 4.4 in $\mathrm{GnRH}$ and $\mathrm{CRH}$ tests, respectively.

From these results, a TSH-producing pituitary tumor was strongly suspected and transsphenoidal hypophysectomy was performed on May 15, 1994. However, complete removal of the tumor was impossible due to tumor invasion to the cavernous sinus. A few days after the operation serum TSH, TSH- $\alpha$, fT3 and fT4 levels transiently decreased to $0.76-0.87 \mathrm{mU} / l, 471$ $\mathrm{pmol} / l, 2.33 \mathrm{pmol} / l$, and $14.9 \mathrm{pmol} / l$, respectively. However, serum TSH and TSH- $\alpha$ levels returned to the pre-operative levels two weeks later. Serum fT3 and fT4 levels were 7.75 $\mathrm{pmol} / l$ and $17.0 \mathrm{pmol} / l$, respectively. The responses of plasma PRL, LH, FSH, GH and ACTH levels to the simultaneous venous administration of TRH, GnRH, GRH and CRH were normal as well as their basal levels. No response of serum TSH level was shown in TRH test. Serum level of SHBG was 68 $\mathrm{nmol} / \mathrm{l}$. The ${ }^{123} \mathrm{I}$ uptake of thyroid gland for 24 hours was $27 \%$ and basal metabolic rate was $1 \%$. Moist skin ameliorated and the patient was discharged on July 15, 1994, and is being followed in the out patient clinic now.

\section{Light microscopic and immunohistochemical findings}

The resected pituitary tumor was pituitary adenoma constituted with chromophobe cells and a few acidophilic cells. Immunohistochemically, anti-TSH antibodies stained the majority of the tumor cells strongly (Fig. 3a). Anti-TSH- $\alpha$ antibodies (Fig. 4a) and anti-TSH- $\beta$ antibodies (Fig. 4b) also stained these cells. Furthermore, tumor cells were stained with antiPRL antibodies (Fig. 3a). Anti-GH antibodies stained the same

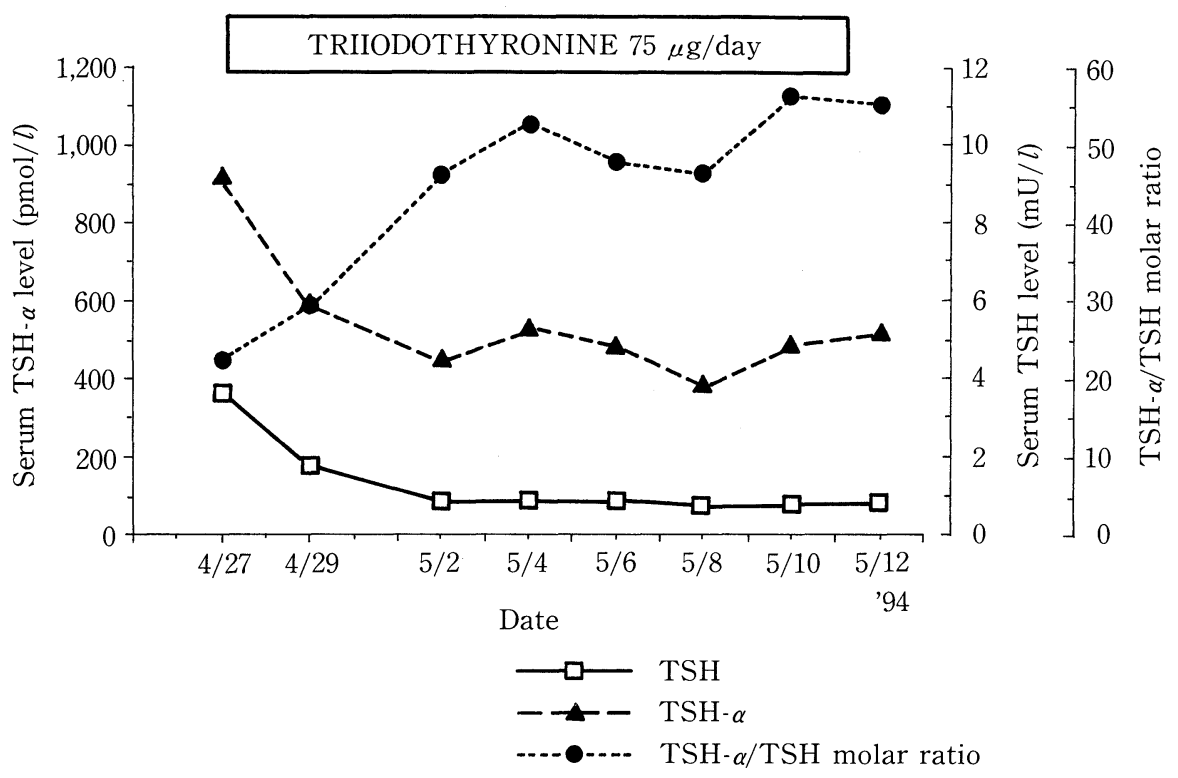

Figure 2. Suppressibility of thyrotropin (TSH) and $\alpha$-subunit of TSH (TSH- $\alpha$ ) by triiodothyronine (T3) administration (T3 suppression test). Serum TSH and TSH- $\alpha$ levels were incompletely suppressed by consecutive oral administration of $75 \mu \mathrm{g}$ of T3 daily for 15 days. The molar ratio of serum levels of TSH- $\alpha$ to TSH gradually increased. During this period serum free T3 levels increased to more than $23.3 \mathrm{pmol} / l$. 

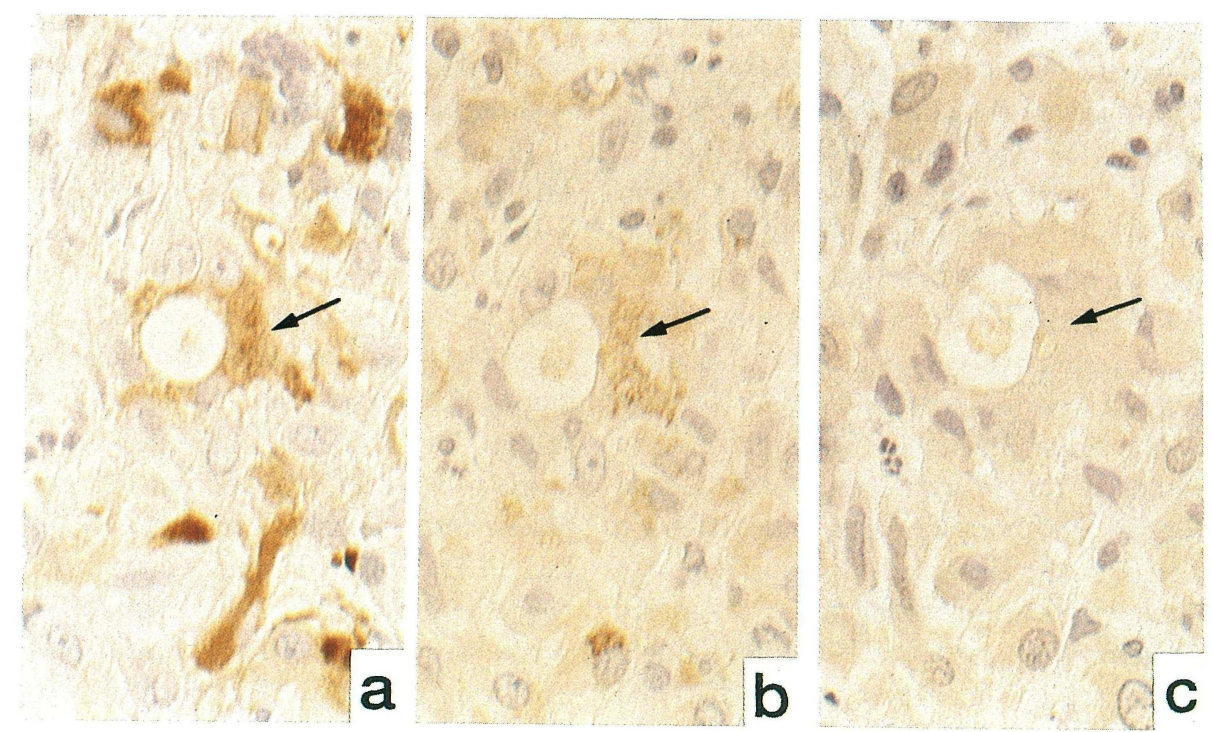

Figure 3. Immunohistochemical staining of $2 \mu$ sections; $a, b$ and $c$ are serial sections of tumor tissue $(\times 400)$. a) TSH immunostaining; b) PRL immunostaining; c) GH immunostaining. Cells have a tendency to have gland formation and each arrow indicates the same cell which was stained with anti-TSH, anti-PRL and anti-GH antibodies, respectively.
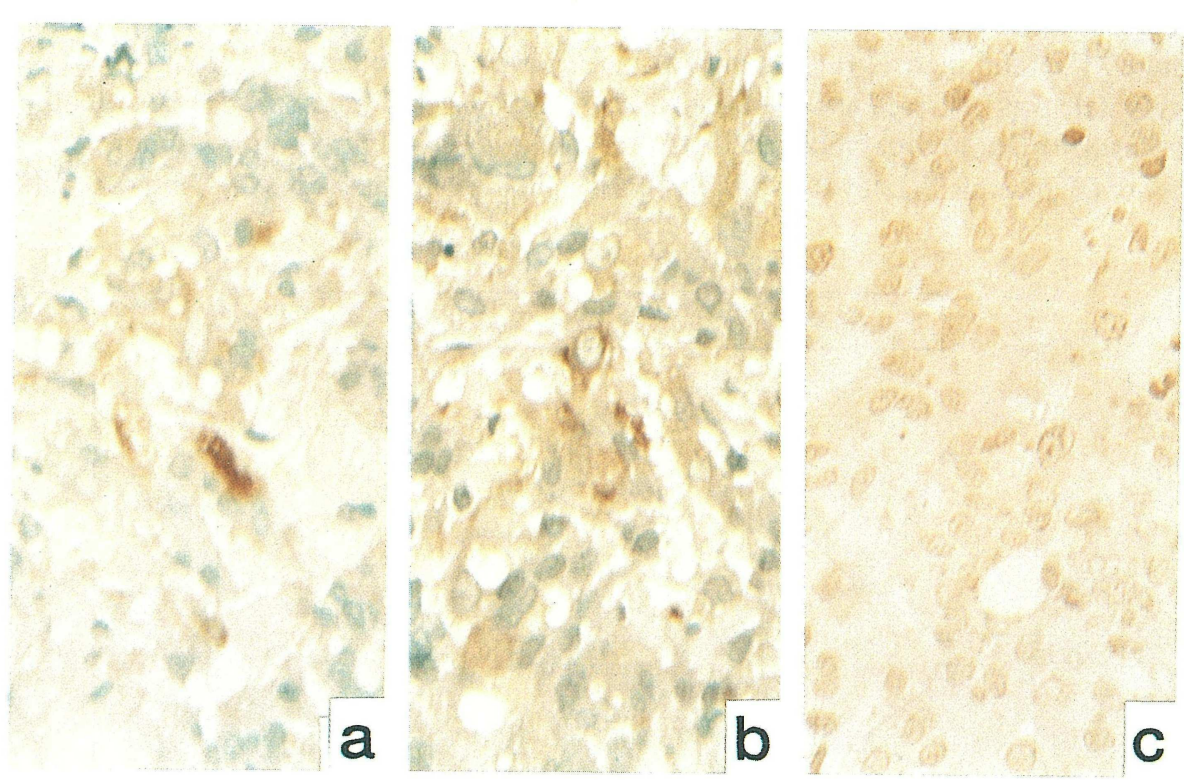

Figure 4. Immunohistochemical staining of $4 \mu$ sections of tumor tissue $(\times 400)$. a) Cytoplasma was stained with anti-TSH- $\alpha$ and $\mathrm{b}$ ) anti-TSH- $\beta$ antibodies, and c) nuclei were stained with anti-Pit-1 antibody.

cells faintly (Fig. 3b). Serial semithin sections revealed that the PRL-positive cells were consistently positive for TSH. A few cells were stained with anti-TSH, anti-PRL and anti-GH antibodies. However, there were no cells stained with anti-LH, antiFSH and anti-ACTH antibodies. Anti-Pit-1 antibodies stained cell nuclei of the adenoma cells (Fig. 4c).

\section{Discussion}

Ambiguous symptoms of hyperthyroidism in this patient 
were supported by normal findings of ${ }^{123}$ I uptake of thyroid gland and the basal metabolic rate. The oxyhyperglycemic pattern of plasma glucose level in glucose tolerance test and the slightly increased serum SHBG level were compatible with hyperthyroidism. The basal serum levels of fT3, fT4, and TSH were consistent with inappropriate secretion of TSH, which includes TSH-producing tumor and selective pituitary resistance to thyroid hormone action (4). The high TSH- $\alpha$ levels and high TSH- $\alpha$ to TSH molar ratios in this patient virtually excluded the diagnosis of the latter $(4,9)$. These results indicate that the pituitary tumor of this patient overproduces TSH, although hyperactivity and autonomity of the tumor is likely limited. The pathogenesis of hyperthyroidism in the setting of normal TSH levels in this patient is poorly understood, but biologic activity of TSH molecules may be increased as previously postulated (10) and reported (3).

The response of serum TSH levels to TRH is variable in patients with TSH-producing pituitary adenoma; about $60 \%$ of reported patients showed no response, which is similar to the present patient (4) and the absence of TRH receptor in such tumors was reported (11). Disappearance of diurnal rhythm of serum TSH level was also consisted with the previously reported patients with TSH-producing tumor $(3,12)$. The decreasing effect of a single administration of bromocriptine on serum TSH and TSH- $\alpha$ levels in this patient may be rather a minor (13), because a majority of the previous patients with TSH-producing tumor did not show a significant fall in serum TSH level (14). However, the reduction of serum TSH level by an acute challenge of somatostatin analog (octreotide acetate) in this patient was consistent with the previous reports $(12,15)$.

The serum TSH level has been reported to be partially suppressed by daily administration of T3 in $25 \%$ of 40 reviewed patients with TSH-producing tumor (4), which was also seen in this patient, and was not suppressed in the remaining patients. It has been reported that the synthesis of both mRNA of alpha and beta subunits of TSH in pituitary cells are suppressed by thyroid hormone. The degree of suppression is greater for TSH$\beta$ than for TSH- $\alpha$ (16). However, the increase of the ratio of TSH- $\alpha$ to TSH during T3 suppression test in this patient indicated that the degree of suppression with $\mathrm{T} 3$ was greater for TSH than for TSH- $\alpha$. Accordingly, TSH- $\beta$ seemed to be conversely more suppressed than TSH- $\alpha$ in this patient. We can postulate one possibility that the gene expression only in TSH$\alpha$-producing cells might have been unsuppressed by T3 administration. In the immunohistochemical examination, however, we could not demonstrate clearly whether tumor cells producing TSH- $\alpha$ alone were present. As another possibility, the $\alpha$ subunit of LH and FSH may have affected this phenomenon, because they were overproduced due to the postmenopausal state of this patient and were not suppressed by T3 administration.

Simultaneous overproduction of PRL and/or GH and/or LH and FSH in TSH-producing pituitary adenoma has been reported (3, 17-19). According to the review of $161 \mathrm{TSH}-$ producing pituitary tumors by Refetoff et al (4), 28 tumors cosecreted PRL, 22 cosecreted GH, and six cosecreted LH and/ or FSH. In the pituitary adenoma in the present patient, we did not examine the secretability of pituitary hormones in vitro. In in vivo studies, we had no evidence of overproduction of pituitary hormones other than TSH. However, we demonstrated a paradoxical increase of plasma GH level in GnRH and CRH tests and demonstrated the synthesis of not only TSH but also PRL and GH by immunohistochemistry. Furthermore, we demonstrated the co-synthesis of TSH, PRL and GH in the same cells as previously reported $(13,20)$. On the other hand, the most frequently occurring variant of plurihormonal adenomas produces GH, PRL and TSH (21), as similarly seen in the adenoma of this patient.

Pit-1 has been known as a pituitary-specific transcription factor that regulates the functional differentiation toward $\mathrm{GH}$, PRL and TSH (22). In a few previous reports, Pit-1 immunoreactivity (19) or its mRNA (23-25) is positive only in adenoma cells producing GH, PRL and/or TSH, but not in the cells producing ACTH, FSH or LH. The results of the present patient are consistent with these reports. Sanno et al postulated from the results of their study about the expression of Pit-1 in TSHproducing adenoma (19) that Pit-1 may have a role in multidirectional differentiation or development of TSH-producing adenoma which may arise from a common progenitor cell. The results of the present case support their report.

Clinically nonfunctioning pituitary adenoma represent 30 to $40 \%$ of pituitary adenomas, and although not resulting in distinct endocrine syndromes, they frequently secrete glycoprotein hormones and/or their free subunit (26). Clinically, the TSH-producing pituitary adenoma of this patient was located close to the nonfunctioning adenoma because of its ambiguous symptoms, although it was histologically plurihormonal pituitary adenoma.

Acknowledgements: We deeply thank Dr. N. Sanno and Dr. Y. Osamura of Tokai University for the immunohistochemical study on TSH- $\beta$ and Pit-1 and Dr. T. Yamaji of the University of Tokyo for the measurement of serum TSH- $\alpha$ levels and giving us anti-TSH- $\alpha$ antibody for the immunohistochemistry, and we also thank Dr. N. Kuzuya of Jichi Medical School and Dr. Y. Kawakami of University of Tsukuba for their kind advice for the study of this case.

\section{References}

1) Thorner MO, Vance ML, Horvath E, Kovacs K. The anterior pituitary. in: Williams Textbook of Endocrinology, 8th Edition, Wilson JD, Foster DW, Eds. WB Saunders Co., Philadelphia, 1992, p.221.

2) Smallridge RC. Thyrotropin-secreting pituitary tumors. Endocrinol Metab Clin North Am 16: 765, 1987.

3) Gesundheit N, Petrick PA, Nissim M, et al. Thyrotropin-secreting pituitary adenomas: clinical and biochemical heterogeneity. Case reports and follow-up of nine patients. Ann Intern Med 111: 827, 1989.

4) Refetoff S, Weis RE, Usala SJ. The syndromes of resistance to thyroid hormone. Endocr Rev 14: 348, 1993.

5) Hall WA, Luciano MG, Doppman JL, Patronas NJ, Oldfield EH. Pituitary magnetic resonance imaging in normal human volunteers: Occult adenomas in the general population. Ann Intern Med 120: 817, 1994.

6) Ingraham HA, Chen R, Mangalam HJ, et al. A tissue-specific transcription factor containing a homeodomein specifies a pituitary phenotype. Cell 55: 519, 1988.

7) Suzuki Y, Takeshita E, Kano S, Hirata S, Sato S. Impaired intestinal 
absorption of thyroid hormone in a case of Hashimoto's disease with antiT3 and anti-T4 antibody. Folia Endocrinol Jpn 58: 1487, 1982.

8) Sanno N, Inada K, Utsunomiya H, Shibuya M, Itoh Y, Osamura RY. Expression of Pit-1 product in human pituitaries: Histological studies by antibody against synthetic human Pit-1. Acta Histochem Cytochem 26: 493, 1993.

9) Kourides IA, Ridgway EC, Weintraub BD, Bigos ST, Gershengorn MC Maloof F. Thyrotropin-induced hyperthyroidism: use of alpha and beta subunit levels to identify patients with pituitary tumors. J Clin Endocrinol Metab 45: 534, 1977.

10) Beck-Peccoz P, Piscitelli G, Amr S, et al. Endocrine, biochemical, and morphological studies of pituitary adenoma secreting growth hormone, thyrotropin (TSH), and alpha-subunit: Evidence for secretion of TSH with increased bioactivity. J Clin Endocrinol Metab 62: 704, 1986.

11) Chanson P, Li JY, Dafniet ML, et al. Absence of receptors for thyrotropin (TSH)-releasing hormone in human TSH-secreting pituitary adenomas associated with hyperthyroidism. J Clin Endocrinol Metab 66: 447, 1988.

12) Beckers A, Abs R, Mahler C, et al. Thyrotropin-secreting pituitary adenomas: report of seven cases. J Clin Endocrinol Metab 72: 477, 1991.

13) Jaquet P, Hassoun J, Delori P, Gunz G, Grisoli F, Weintraub BD. A human pituitary adenoma secreting thyrotropin and prolactin: Immunohistochemical, biochemical, and cell culture studies. J Clin Endocrinol Metab 59: $817,1984$.

14) Bevan JS, Burke CW, Esiri MM, et al. Studies of two thyrotrophinsecreting pituitary adenomas: Evidence for dopamine receptor deficiency. Clin Endocrinol (Oxf) 31: 59, 1989.

15) Wemeau JL, Dewailly D, Leroy R, et al. Long term treatment with the somatostatin analog SMS 201-995 in a patient with a thyrotropin- and growth hormone-secreting pituitary adenoma. J Clin Endocrinol Metab 66: $636,1988$.

16) Chin WW, Shuprik MA, Ross DS, Hábener JF, Ridgway EC. Regulation of the alpha and thyrotropin beta-subunit messenger ribonucleic acids by thyroid hormones. Endocrinology 116: 873, 1985.

17) Lamberg BA, Ripatti J, Gordin A, Juustila H, Sivula A, Bjorkesten G. Chromophobe pituitary adenoma with acromegaly and TSH-induced hyperthyroidism associated with parathyroid adenoma. Acta Endocrinol 60: $157,1969$.

18) Duello TM, Halmi NS. Pituitary adenoma producing thyrotropin and prolactin. Virchows Arch Pathol Anat Histol 376: 255, 1977.

19) Sanno N, Teramoto A, Matsuno A, Inada K, Itoh J, Osamura RY. Clinical and immunohistochemical studies on TSH-secreting pituitary adenoma: Its multihormonality and expression of Pit-1. Modern Pathol 7: 893, 1994.

20) Terzolo M, Orlandi F, Bassetti M, et al. Hyperthyroidism due to a pituitary adenoma composed of two different cell types, one secreting alphasubunit alone and another cosecreting alpha-subunit and thyrotropin. $\mathrm{J}$ Clin Endocrinol Metab 72: 415, 1991.

21) Scheihauer BW, Horvath E, Kovacs K, Laws ER Jr, Randall RV, Ryan N. Plurihormonal pituitary adenoma. Semin Diag Pathol 3: 69, 1986.

22) Simmons DW, Voss JW, Ingraham HA, et al. Pituitary cell phenotypes involve cell-specific Pit-1 mRNA translation and synergistic interactions with other transcription factors. Gene Dev 4: 695, 1990.

23) Asa SL, Puy LA, Lew AM, Sundmak VC, Elscholtz HP. Cell typespecific expression of the pituitary transcription activator Pit-1 in the human pituitary and pituitary adenomas. J Clin Endocrinol Metab 77: 1275, 1993.

24) Friend KE, Chiou YK, Laws Jr ER, Lopes MBS, Shupnik MA. Pituitary messenger ribonucleic acid is differentially expressed in human pituitary adenomas. J Clin Endocrinol Metab 77: 1281, 1993.

25) Pellegrini I, Barlier A, Gunz G, et al. Pit-1 gene expression in the human pituitary and pituitary adenoma. J Clin Endocrinol Metab 79: 189, 1994.

26) Klivanski A. Nonsecreting pituitary tumors. Endocrinol Metab Clin North Am 16: 793, 1987. 